\title{
Pengembangan Penuntun Praktikum Ekologi Tumbuhan Berbasis Literasi Sains
}

\author{
Tini Rosalia Gultom, Binari Manurung, Fauziyah Harahap \\ Program Studi Pendidikan Biologi, Program Pascasarjana, Universitas Negeri Medan
}

\begin{abstract}
Abstrak: Penelitian ini bertujuan untuk mengetahui tingkat kelayakan; (1) Penuntun praktikum Ekologi Tumbuhan Berbasis Literasi Sains sebagai batang tubuh pengetahuan (a body of knowladge; (2) Penuntun praktikum Ekologi Tumbuhan Sains sebagai cara untuk menyelidiki (way of investigating); (3) Penuntun praktikum Ekologi Tumbuhan Sains sebagai cara berfikir (way of thinking); (4) Penuntun praktikum Ekologi Tumbuhan Interaksi sains, teknologi dengan masyarakat (interaction of science, tecnology and society) menurut tim ahli materi, ahli desain dan mahasiswa biologi Universitas Negeri Medan. Jenis penelitian ini adalah penelitian pengembangan produk model Borg and Gall, yang dimodifikasi sesuai kebutuhan. Model ini meliputi enam tahapan, yaitu (1) Melakukan penelitian pendahuluan; (2) Perencanaan produk; (3) Pengumpulan bahan; (4) Pengembangan produk awal; (5) Validasi produk, (6) Revisi dan Uji Coba. Subjek uji coba terdiri dari tim ahli materi, tim ahli desain. Data dianalisis dengan tehnik deskriftif kualitatif dan kuantitatif. Hasil penelitian pengembangan penuntun praktikum berbasis literasi sains menurut tim ahli materi (dua) menunjukkan bahwa tingkat kelayakan Penuntun praktikum Ekologi Tumbuhan Berbasis Literasi Sains (1) Sebagai batang tubuh pengetahuan (a body of knowladge) "sangat baik" (91,07\%); (2) Sebagai cara untuk menyelidiki (way of investigating) "sangat baik" (100\%); (3) Sebagai cara berfikir (way of thinking) "sangat baik" (92,18\%); (4) Interaksi sains, teknologi dengan masyarakat (interaction of science, tecnology and society) dan refleksi diri "sangat baik" (96,87\%); (5) menurut tim ahli desain "sangat baik" 92,10\%. Berdasarkan data tersebut produk penuntun praktikum Ekologi Tumbuhan Berbasis Literasi Sains yang sudah dikembangkan layak digunakan untuk mahasiswa sebagai penuntun praktikum pada mata kuliah Ekologi Tumbuhan.
\end{abstract}

Kata Kunci: Pengembangan Penuntun praktikum, Ekologi Tumbuhan, Literasi sains

\section{PENDAHULUAN}

Praktikum merupakan bagian integral dari kegiatan belajar mengajar. Praktikum menjadi sarana pengenalan bahan dan peralatan yang semula dianggap abstrak menjadi lebih nyata sehingga peserta didik lebih memahami konsep-konsep biologi Ekologi Tumbuhan.

Berdasarkan kondisi yang terjadi pada saat ini, literasi sains Indonesia masih tertinggal cukup jauhdibandingkan dengan negara lain. Hasil studiinternasional melalui Programme for InternationalStudent Assesment (PISA) dapat dijadikan rujukanmengenai rendahnya literasi sains anak-anak Indonesiadibandingkan dengan negara lain (Firman, 2007).

Studi awal yaitu studi dokumentasi penulis mengenai penuntun praktikum Ekologi Tumbuhan di Universitas Negeri Medan khususnya di jurusan Pendidikan biologi bahwa pengembangan materi belum dilakukan dan belum menggunakan penuntun praktikum yang mengandung empat komponen literasi sains yaitu sains sebagai batang tubuh pengetahuan ( $a$ body of knowladge), sains sebagai cara berfikir (way of thinking) sains sebagai cara untuk menyelidiki (way of investigating) dan sains sebagai interaksi sains, teknologi dengan masyarakat (interaction of science, tecnology and society) yang melibatkan aspek-aspek yang mengandung literasi sains yaitu konten, proses dan konteks (Adisendjaja, 2009).

Siswa tidak terlepas saat dia mendapatkan pengetahuan dari guru yang mengajar sewaktu proses belajar mengajar serta guru juga tidak terlepas saat dia mengikuti perkuliahan di Universitas yang guru jalanin sehingga calon guru (Mahasiswa) perlu dibenahi saat calon guru mengikuti perkuliahan dan diberikan sumber bacaan yang mengandung empat komponen literasi sains dan dan didalam literasi sains juga terdapat refleksi diri 
sehingga selama perkuliahan calon guru sudah mengetahui dan memahami literasi sains dan sangat mendesak untuk dikembangkan penuntun praktikum Ekologi Tumbuhan berbasis literasi sains.

\section{TUJUAN PENELITIAN}

Penelitian ini bertujuan Untuk mengetahui bagaimana kelayakan penuntun praktikum Ekologi Tumbuhan berbasis literasi sains sebagai batang tubuh pengetahuan (a body of knowlagde), sains sebagai cara untuk menyelidiki (way of investigating), sains sebagai cara berfikir (way of thinking) dan sains sebagai interaksi sains, teknologi dengan masyarakat (interaction of science, tecnology and society).

\section{METODE PENELITIAN}

Jenis penelitian ini adalah penelitian pengembangan produk model Borg and Gall, yang dimodifikasi sesuai kebutuhan. Model ini meliputi enam tahapan, yaitu (1) Melakukan penelitian pendahuluan; (2) Perencanaan produk; (3) Pengumpulan bahan; (4) Pengembangan produk awal; (5) Validasi produk, (6) Revisi dan Uji Coba. Subjek uji coba terdiri dari tim ahli materi, tim ahli desain. Data dianalisis dengan tehnik deskriftif kualitatif dan kuantitatif (Sugyono, 2011).

\section{HASIL DAN PEMBAHASAN}

Hasil penelitian pengembangan penuntun praktikum berbasis literasi sains menunjukkan bahwa: (1) Penuntun praktikum Ekologi Tumbuhan Berbasis Literasi Sains sebagai batang tubuh pengetahuan (a body of knowladge) "sangat baik" (91,07\%); (2) Penuntun praktikum Ekologi Tumbuhan Sains sebagai cara untuk menyelidiki (way of investigating) "sangat baik" (100\%); (3) Penuntun praktikum Ekologi Tumbuhan Sains sebagai cara berfikir (way of thinking) "sangat baik" (92,18\%); (4) Penuntun praktikum Ekologi Tumbuhan Interaksi sains, teknologi dengan masyarakat (interaction of science, tecnology and society) dan Refleksi Diri "sangat baik" $(96,87 \%)$.
Hasil penelitian Arwita (2012) berjudul "Pengembangan Bahan Ajar Biologi Berdasarkan Literasi Sains pada Materi Archebacteria dan Eubacteria untuk kelas X SMA/MA “ menggunakan model pengembangan Borg dan Gall, menyimpulkan bahwa buku ajar biologi hasil pengembangan memperoleh penilaian yang sangat baik validasi terhadap kelayakan isi penyajian dan desain pembelajaran serta penerapan literasi sains sangat diperlukan untuk kebutuhan sains siswa di masa yang akan datang.

Hasil validasi dari ali desain teradap kelayakan desain dalam pengembagan Penuntun praktikum Ekologi Tumbuhan berbasis Literasi sains untuk mahasiswa yang dikembangkan menunjukkan bahwa sangat baik/sangat layak. Hal ini sesuai dengan pendapat Zuriyanti (2009)menyatakan bahwa produk hasil pengembangan yang suda dilakukan revisi berdasarkan masukan dan saran dari validator layak digunakan jika desain produk telah mendapat penilaian minimal berkategorikan sangat layak. Hal tersebut didukung kemenarikan warna dan ilustrasi desain sampul Penuntun praktikum serta bagian isi, Penuntun praktikum, seingga dapat memperjelas konsep, pesan dan gagasan yang disampaikan dalam penuntun praktikum.

Menurut Depdiknas (2008) dalam pembuatan ilustrasi yang benar dapat memicu peserta didik dalam membaca kemudian ditambahkan dengan tata letak yang tepat dapat membuat bahan ajar lebih menarik untuk dibaca sehingga akan timbul niat untuk serta dapat memotivasi peserta didik untuk menggunakan bahan ajar dalam pembelajaran. Dengan adanya kombinasi warna dan ilustrasi yang menarik memegang peranan penting dalam bahan ajar yang akan dikembangkan.

Berdarkan data-data yang sudah diperoleh dari mahasiswa bahwa Penuntun praktikum Ekologi Tumbuhan berbasis Literasi sains untuk mahasiswa prodi Pendidikan Biologi/Biologi yang dikembangkan sesuai dengan penilaian indikator dalam pernyataan secara keseluruan dengan kriteria "sangat baik". 
Sesuai dengan penjelasan Depdiknas (2004) bahwa bahan bacaan dapat membantu peserta didik dalam menambah informasi. Data hasil respon mahasiswa terhadap Penuntun praktikum yang dikembangkan mengalami peningkatan yaitu terjadi peningkatan sebesar $9,7 \%$ dari uji coba kelompok kecil dan peningkatan 3,9\% dari uji coba kelompok kecil ke uji coba kelompok lapangan terbatas.

\section{KESIMPULAN}

Penuntun praktikum Ekologi Tumbuhan berbasis literasi Sains sebagai batang tubuh pengetahuan (a body of knowladge) termasuk krteria "sangat Baik" dengan persentase rata-rata $91,07 \%$ sehingga sehingga dapat diterima dan layak digunakan sebagai bahan ajar tambahan dikelas. Penuntun praktikum Ekologi Tumbuhan berbasis literasi Sains sebagai cara untuk menyelidiki (way of investigating) termasuk kriteria "sangat baik" dengan persentase rata-rata $100 \%$ sehingga penuntun praktikum dapat layak digunakandalam pengantar mahasiswa dalam melakukan kegiatan praktikum. Penuntun praktikum Ekologi Tumbuhan berbasis literasi sains sebagai cara cara berfikir (way of thinking) termasuk kriteria "sangat Baik" dengan persentase rata-rata $92,18 \%$ sehingga dapat diterima dan layak digunakan sebagai bahan ajar secara mandiri agar lebih mudah memahami pelajaran. Penuntun praktikum Ekologi Tumbuhan berbasis literasi Interaksi sains, teknologi dengan masyarakat (interaction of science, tecnology and society) dan Refleksi Diri termasuk kriteria "sangat baik" dengan persentase rata-rata 96,87\% sehingga dapat diterima dan layak digunakan sebagai baan ajar yang menyajikan kegunaan ilmiah sains dan teknologi bagi masyarakat.

\section{DAFTAR PUSTAKA}

Adisendjaja, Y.H. (2009). Analisis Buku Ajar Biologi Sma Kelas X Di Kota Bandung Berdasarkan Literasi Sains, Bandung: Pendidikan Biologi FMIPA Universitas Pendidikan Indonesia.

Depdiknas. (2004). Pengembangan Bahan Ajar. Jakarta: Direktorat Dikmenum.

Depdiknas. (2008). Penulisan Modul. Jakarta: Ditjen PMPTK Depdiknas.

Firman, H. (2007). Analisis Literasi Sains Berdasarkan Hasil PISA Nasional Tahun 2006. Jakarta: PusatPenilaian Pendidikan Balitbang Depdiknas.

Sugyono. (2011). Metode penelitian kuantitatif dan $R \& D$. Bandung: Alfabeta.

Zuriyanti, (2009).Literasi Sains dan Pendidikan. Surabaya: Jurusan Biologi, FMIPA Universitas Negeri Surabaya. 